\title{
TEXTO, DISCURSO E ENSINO de ELISA GUIMARÃES
}

\author{
Dina Maria Martins Ferreira*
}

\begin{abstract}
$\mathrm{Na}$ 'práxis' do uso da linguagem, um parceiro enuncia as palavras, o outro age de acordo com elas; na lição de linguagem, porém, encontrar-se-á 'este' processo:

o que aprende 'denomina' os objetos. Isto é, fala a palavra (...) Podemos também imaginar que todo o processo do uso das palavras é um daqueles jogos por meio dos quais as crianças aprendem sua língua materna (...) Pense os vários usos das palavras ao se brincar de roda (...) Chamarei também de 'jogos de linguagem' o conjunto da linguagem e das atividades com as quais está interligada.
\end{abstract}

(Wittgenstein, 1989:12)

\section{RESENHA}

GUIMARÃES, Elisa. Texto, discurso e ensino. São Paulo: Contexto, 2009.

A obra recente, lançada em final de 2009, da professora doutora Elisa Guimarães é reflexo de um percurso de estudiosa preocupada com o leitor e principalmente com o aluno. As relações entre autor e leitor, entre professor e aluno, entre ensino e aprendizagem já se esboçam no primeiro folhear do livro, desde o seu título à organização, que já aguçam a vontade de mergulhar em sua trama conteudística. Elisa Guimarães retrata em sua obra "o conhecimento compreensivo e íntimo que não nos separa do científico, e sim nos une pessoalmente ao que estudamos" (Santos, 1998:68).

Sua obra Texto, Discurso e Ensino reflete o seu saber e sua experiência no percurso acadêmico. A começar pelo ensino, demonstra que o mesmo não se agencia

\footnotetext{
* Dina Maria Martins Ferreira, atualmente, está em seu segundo pós-doutoramento com hospedagem acadêmica na Universidade Estadual de Campinas/Unicamp, Instituto de Estudos da Linguagem/IEL (São Paulo, Brasil), junto a Université Paris-V, Sorbonne e Centre des Études des Actuels e du Quotidien/CEAQ (Paris, França), é professora-pesquisador licenciada da Universidade Mackenzie.
} 
apenas por conceitos e palavras estáticas. Sua escolha de excertos para o percurso da aprendizagem se faz detalhista e minuciosa, instigando a vontade de continuar no caminho da vida da linguagem - texto e discurso. Figuras, argumentações e excertos sorriem para o leitor. A tríade temática compõe o vitalismo de sua obra, na medida em que pensar linguagem no ensino é percorrer o mundo textual e discursivo e pensar em ensino é tocar os sujeitos do mundo. A autora mostra que a tríade temática - texto, discurso e ensino - constrói uma teia responsiva em que um não se atualiza sem o outro; as agências de proliferam entre aquele que fornece o saber, e aqueles que o recebem, construindo um espiral contínuo e ininterrupto de trocas: "os temas são galerias por onde os conhecimentos progridem ao encontro uns dos outros" (Santos, 2005: 65).

$\mathrm{E}$ as folhas continuam a ser lidas. Estou percorrendo quatro capítulos. Nos dois primeiros, vejo-me diante de conceituações pertinentes de texto e discurso, em que se apresentam as relações extensivas que se processam nos dois níveis de linguagem, de modo a instrumentalizar uma prática comunicativa eficaz. No que se refere a Texto, discorre detalhadamente sobre a constituição textual, com seus variáveis tipos, sua forma de organização e seus níveis de construção, que desaguam na progressão temática e seus implícitos. No que tange ao Discurso, não deixa de lado os tópicos relevantes, que extrapolam a matéria linguística e que abraçam o sentido social da linguagem. E nesse abraço, descortina as formações ideológicas que permeiam as discursivas, premiadas pela ponte da interdiscursividade. No capítulo três premia o leitor pelas relações limítrofes e de convergências que ocorrem entre os níveis textual e discursivo, oferecendo mecanismos operacionais que as constituem. E no último capítulo, engenhosamente, relaciona a unidade triádica constitutiva de sua obra - texto, discurso e ensino -, em que sintonias e nexos entre as partes se fazem relevantes para o conhecimento da língua(gem) e da pedagogia de língua materna. A análise textual final não fecha a cortina, pelo contrário, abre um palco de possibilidades para encenar uma cadeia de aprendizagem.

É como diz Ludwig Wittgenstein, "representar uma linguagem significa representar-se uma forma de vida" (Wittgenstein, 1989: 15). E fazendo uma metáfora relacional com a obra, poderia dizer que a autora 'representa uma linguagem' com as regras do conhecimento sobre texto e discurso para constituir uma nova 'forma de vida' no mundo do ensino e aprendizagem. E ao terminar a última folha, verifico que o conhecimento está em vida e não apenas falando sobre a vida linguageira (Ferreira e Rajagopalan, 2006). E a epígrafe confirma o valor didático da obra: pratica e instrumentaliza a comunicabilidade, oferece lição de linguagem e possibilita a aprendizagem da língua materna, formando um "conjunto da linguagem e das atividades com as quais está interligada" (Wittgenstein, 1989:12).

A obra se perfila pela seriedade no saber e pela preocupação com o Outro. O Euautor de Elisa Guimarães está em construto com seu Outro-leitor-mundo. Cabe a todos, que tiverem o privilégio dessa leitura, desfrutá-la na sua aprendizagem e na sua prática docente. Elisa Guimarães cumpre o seu papel de cientista da linguagem:

(...) é necessário que cada ser humano que pensa tenha a possibilidade de participar com toda lucidez dos grandes problemas científicos de sua época (...) É somente quando cumpre 
essa importante missão que a ciência adquire, do ponto de vista social, o direito de existir (Einstein, citado em Tageblatt, 2005:6).

\section{Referências Bibliográficas:}

FERREIRA, Dina M. M. \& RAJAGOPALAN, Kanavillil. Políticas em linguagem: perspectivas identitárias. São Paulo: Ed. Mackenzie, 2006.

SANTOS, Boaventura de Souza. Um discurso sobre as ciências na transição para uma ciência pós-moderna. Estudos Avançados vol. 2 nº. 2, São Paulo, 1988 [artigo também publicado no livro Um discurso sobre as ciências. $4^{\mathrm{a}}$.ed. São Paulo: Cortez, 2006].

TAGEBLATT, B. "Veja o que Einstein pensava sobre a relevância da divulgação científica". Jornal de Ciência e Tecnologia. Agosto, 2005.

WITTGENSTEIN, Ludwig. Investigações Filosóficas. Os Pensadores. (tradução José Carlos Bruni). São Paulo: Nova Cultural, 1989. 